\title{
Unusual low-grade neuroepithelial tumour with novel PDGFRA mutation
}

\author{
Yan Yuen Lo, ${ }^{1}$ Denise Malicki, ${ }^{2}$ Michael Levy, ${ }^{3}$ John Ross Crawford ${ }^{4}$
}

'Department of Neurosciences, University of California San Diego, La Jolla, California, USA ${ }^{2}$ Department of Pathology, Rady Children's Hospital University of California San Diego, San Diego, California, USA

${ }^{3}$ Department of Neurosurgery, University of California San Diego, San Diego, California, USA

${ }^{4}$ Departments of Neurosciences and Pediatrics, University of California San Diego, La Jolla, California, USA

Correspondence to Dr John Ross Crawford; jrcrawford@ucsd.edu

Accepted 30 October 2021

Check for updates

(c) BMJ Publishing Group Limited 2021. No commercial re-use. See rights and permissions. Published by BMJ.

To cite: Lo YY, Malicki D, Levy M, et al. BMJ Case Rep 2021;14:e247411. doi:10.1136/bcr-2021247411

\section{DESCRIPTION}

An 8-year-old girl presented with precocious puberty and an otherwise normal examination. MRI of the pituitary was normal; however, an incidental oval, non-enhancing T2 hyperintense lesion in the right temporal subcortical white matter was identified (figure 1). The neuro-radiographic differential diagnosis included a low-grade glioma, dysembryoplastic neuroepithelial tumour or atypical cortical dysplasia. She underwent a robotic-guided biopsy where pathology revealed cortical areas with slightly increased cellularity, evenly distributed and containing scattered disoriented neurons, with some portions showing a loosely structured architecture and mildly myxoid background. Immunochemistry tested positive for glial fibrillary acidic protein and NeuN1, consistent with a histologic diagnosis of a low-grade neuroepithelial tumour (figure 2). Next general sequencing of the tumour revealed a mutation of PDGFRA p.K385L and variants of unknown mutations of GRM3p.875s and NOTCH1 $p R 2431 \mathrm{~W}$. Tumour microarray showed no copy number alterations. The patient is without progressive disease on follow-up MRIs 2 years after diagnosis.

Paediatric low-grade gliomas (pLGG) account for approximately $30 \%$ of paediatric brain tumours and encompass a wide range of histologic and molecular entities as defined by the WHO classification. ${ }^{12}$ Although pLGG rarely transforms to higher grade tumours as seen in adults, the outcome and therapeutic response has been highly variable, making treatment challenging. Low-grade neuroepithelial tumour is a type of low-grade glioneuronal tumour with a wide spectrum of variable features in genetic variations, commonly associated with epilepsy in young adults and children. Molecular profiling of pLGG identified key genetic alteration in the RASmitogen-activated protein kinase (RAS/MAPK) pathway often involving somatic alterations of germline NF1 or BRAF. ${ }^{2}{ }^{3}$ Rarer common pLGG alterations include RAS/MAPK alterations such as FGFR1/2/3, NTRK2, RAF1, ALK and ROS1, and non-RAS/MAPK alterations such as $M Y B$, MYBL1, IDH1 and H3F3A. ${ }^{2}{ }^{4}$ Recent work has characterised pLGG into a variety of molecular subgroups based on molecular signatures. ${ }^{2}$ Even in patients who did not have identifiable mutations, single sample gene set enrichment analysis demonstrated increased activation signature in the RAS-MAPK pathway compared with normal brain controls, indicating pathway upregulation even in the absence of a clear molecular driver. ${ }^{2}$

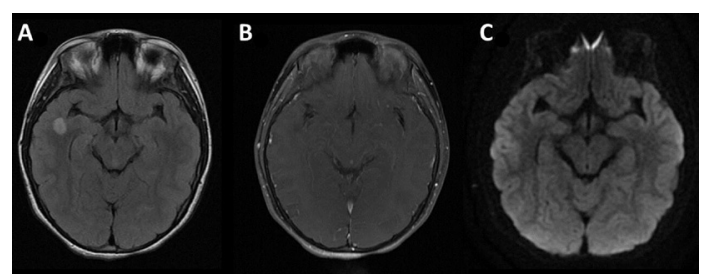

Figure 1 Neuroimaging features of low-grade neuroepithelial tumour. MRI reveals a hyperintense temporal lobe mass on fluid-attenuated inversion recovery sequences $(A)$, without post-gadolinium enhancement (B) or reduced diffusivity (C).

Platelet-derived growth factor receptor $\alpha$ (PDGFRA) gene mutations are more commonly associated with gastrointestinal stromal tumours which occur in the gastrointestinal tract such as the stomach or the small intestine. ${ }^{5}$ PDGFRA gene mutation in brain tumours is novel at large. Specifically, the PDGFRA p.K385-mutant is a novel tumour entity of the central nervous system (CNS) with the PDGFRA p.K385-mutant. Molecularly, the PDGFRA p.K385-mutant contains a defined dinucleotide mutation at codon 385 of the PDGFRA oncogene where lysine is replaced by either isoleucine or leucine. Optimal treatment and clinical outcome of the PDGFRA p.K385mutant is yet to be defined. ${ }^{6}$

We present a low-grade neuroepithelial tumour with a unique PDGFRA mutation that may fit into the category of the recently described

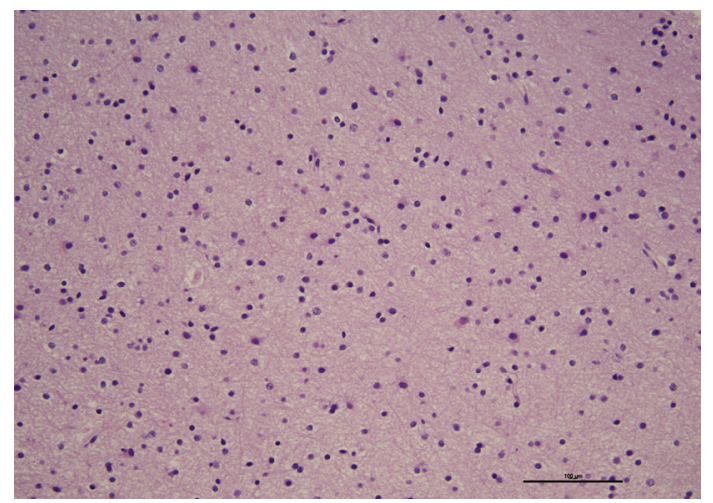

Figure 2 Neuropathologic features of low-grade neuroepithelial tumour. Haematoxylin eosin biopsy specimens reveal increased cellularity with scattered disoriented neurons in a mildly myxoid background. Immunohistochemistry (not shown) was diffusely positive for glial fibrillary acidic protein (GFAP) and scantly positive for NeuN1 positivity consistent with a histologic diagnosis of a low-grade neuroepithelial tumour. 
polymorphous low-grade neuroepithelial tumour of the young. ${ }^{7}$ Given the novelty in the genetic mutation, the role and significance the PDGFRA p.K385-mutant plays in tumour growth is unknown.

\section{Learning points}

- Platelet-derived growth factor receptor $\alpha$ (PDGFRA) gene mutations are commonly associated with tumours in the gastrointestinal tract and are less commonly associated with paediatric brain tumours.

- We present a case of low-grade glioma with novel mutation in the PDGFRA p.K385L gene and several variants of unknown significance that may fit into the spectrum of the recently described polymorphous low-grade neuroepithelial tumour of the young.

- Next generation sequencing and microarray can provide important tumour characterisation in paediatric low-grade glioma and guide future studies in phenotype-genotype correlations.

Contributors YYL, DM, ML and JRC were responsible for the design and creation of the case report.

Funding The authors have not declared a specific grant for this research from any funding agency in the public, commercial or not-for-profit sectors.
Competing interests None declared.

Patient consent for publication Consent obtained from parent(s)/guardian(s).

Provenance and peer review Not commissioned; externally peer reviewed.

Case reports provide a valuable learning resource for the scientific community and can indicate areas of interest for future research. They should not be used in isolation to guide treatment choices or public health policy.

\section{REFERENCES}

1 Huse JT, Snuderl M, Jones DTW, et al. Polymorphous low-grade neuroepithelial tumor of the young (PLNTY): an epileptogenic neoplasm with oligodendroglioma-like components, aberrant CD34 expression, and genetic alterations involving the MAP kinase pathway. Acta Neuropathol 2017:133:417-29.

2 Ryall S, Zapotocky M, Fukuoka K, et al. Integrated molecular and clinical analysis of 1,000 pediatric low-grade gliomas. Cancer Cell 2020:37:569-83.

3 Collins VP, Jones DTW, Giannini C. Pilocytic astrocytoma: pathology, molecular mechanisms and markers. Acta Neuropathol 2015;129:775-88.

4 Petralia F, Tignor N, Reva B, et al. Integrated Proteogenomic characterization across major histological types of pediatric brain cancer. Cell 2020;183:e31:1962-85.

5 PDGFRA gene: MedlinePlus Genetics. Medlineplus.gov, 2021. Available: https:// medlineplus.gov/genetics/gene/pdgfra/\#: :text=Mutations $\% 20$ in $\% 20$ the\% 20PDGFRA\%20gene\%20are\%20associated\%20with\%20gastrointestinal\%20stromal, gene $\% 20$ occur\% 20 in $\% 20$ the\%20stomach [Accessed 8 Oct 2021].

6 Lucas C-HG, Villanueva-Meyer JE, Whipple N, et al. Myxoid glioneuronal tumor, PDGFRA p.K385-mutant: clinical, radiologic, and histopathologic features. Brain Pathol 2020;30:479-94 https://onlinelibrary.wiley.com/doi/epdf/10.1111/bpa.12797

7 Ida CM, Johnson DR, Nair AA, et al. Polymorphous low-grade neuroepithelial tumor of the young (PLNTY): molecular profiling confirms frequent MAPK pathway activation. J Neuropathol Exp Neurol 2021;80:821-9.

Copyright 2021 BMJ Publishing Group. All rights reserved. For permission to reuse any of this content visit

https://www.bmj.com/company/products-services/rights-and-licensing/permissions/

BMJ Case Report Fellows may re-use this article for personal use and teaching without any further permission.

Become a Fellow of BMJ Case Reports today and you can:

- Submit as many cases as you like

- Enjoy fast sympathetic peer review and rapid publication of accepted articles

- Access all the published articles

Re-use any of the published material for personal use and teaching without further permission

Customer Service

If you have any further queries about your subscription, please contact our customer services team on +44 (0) 2071111105 or via email at support@bmj.com.

Visit casereports.bmj.com for more articles like this and to become a Fellow 